\title{
THE EFFECT OF PHYSICAL ACTIVITY ON WEIGHT DECREASE OF OBESITY STUDENTS AT SMK NEGERI 3 SALATIGA
}

\author{
*Angkit Kinasih, Kristiawan Prasetyo Agung Nugroho, Nur Sugiharso \\ Correspondence: Satya Wacana Christian University, Salatiga \\ E-mail: angkit.kinasih@uksw.edu
}

\begin{abstract}
Adolescent obesity occurs because it requires more nutritional intake to support the growth process and sometimes without being balanced with a healthy lifestyle and lack of physical activity. The research objective was to determine the effect of physical activity on weight loss of obese students at SMK Negeri 3 Salatiga. This type of quantitative research with a quasi-experimental model. There were 20 students in class X and XI with BMI>27 kg / m2. Physical activity undertaken is a pattern of aerobic physical exercises such as jogging, push ups, and sit ups for 3 times a week with a duration of 30 minutes for 1 month. Analysis of research data includes the stages of univariate data analysis including descriptive information from respondents and analysis of bivariate data using Paired Samples T Test. The results of this study have reduced body weight by $3 \%$ with physical exercise in the form of jogging, push ups, and sit ups.
\end{abstract}

\section{Keywords: Physical Activity, Obesity, Adolescents, Salatiga}

\section{Introduction}

Obesity is a condition in which a person has a body weight above normal or more than $27 \mathrm{~kg} / \mathrm{m} 2$ (Nurcahyo, 2011). In 2013, the obesity rate in Indonesia's adolescent population reached $1.6 \%$ compared to cases of obesity which reached $5.7 \%$ (KEMENKES, 2013). Obesity is a major health problem today.

According to (Sofa, 2018), a person with obesity tends to have visceral fat in the body. Visceral fat is body fat that collects in the center of the body and covers the surrounding organs. Excess visceral fat in the body will increase a person's risk of developing complications from obesity, namely cardiovascular disease and metabolic syndrome such as hypertension, dyslipidemia, diabetes mellitus type II, and insulin retention (Kosnayani \& Aisyah, 2016).

Obesity can attack all age groups, but the group that is susceptible to obesity is adults (Turege et al., 2019). Based on research conducted by (Aini, 2013), obesity can also occur in adolescents aged 10-18 years. Obesity in adolescents can occur because at this age a person needs more nutrition to support the growth process, so this affects eating habits without being balanced by a healthy lifestyle. According to (Kurdanti et al., 2015), besides lack of physical activity and irregular eating patterns, obesity in adolescents is also influenced by gender which can cause changes in a person's body and changes in energy balance. According to research (Kurdanti et al., 2015), the incidence of obesity is

PJKR

https://jurnal.unimed.ac.id/2012/index.php/jpehr 
greater in men than in women because men tend to spend their free time relaxing on weekends. The data obtained from a preliminary study conducted by researchers at SMK Negeri 3 Salatiga showed that the total number of students in grade $\mathrm{X}$ and $\mathrm{XI}$ was 880 and there were 20 obese male students with a BMI above $>27 \mathrm{~kg} / \mathrm{m} 2$.

Advances in technology have made things easier. But behind the conveniences offered, technological advances make lifestyles less mobile. This makes the physical activity of adolescents very inadequate and at risk of causing various kinds of diseases later in life, including obesity (Sari et al., 2017). One way to avoid obesity is physical activity.

Physical activity is any movement of the body carried out by the skeletal muscles which can produce energy expenditure which is expressed in units of kilo calories (Harikedua \& Tando, 2012). Physical activity is a means of channeling excess energy and burning excess fat in the body so as to prevent obesity. According to (Yuksel et al., 2020) to the intervention has an important role in preventing obesity if the focus is on physical activity. Exercise that is done in an appropriate and regular way can help you lose weight (Nurcahyo, 2011). The recommended sport is aerobic exercise, namely sports that use oxygen in the energy formation system. The type of exercise that is intended is exercise that is not too strenuous but is done in more than 15 minutes. Examples of sports that are recommended include walking for 20-30 minutes every day, swimming, cycling, jogging, aerobics, and so on (Wijayanti, 2013).

According to (Wijayanti, 2013), research conducted at SMA Negeri 3 Temanggung stated that there were 28 students who were obese due to several factors, namely that some students had been obese since childhood, consumed lots of snacks, and lack of physical activity. The results obtained from the research conducted by (Wijayanti, 2013) can be concluded that aerobic exercise is carried out for 4 weeks, with a frequency of 3 times per week with the applied dietary arrangement.

Based on this background, researchers are interested in knowing the effect of physical activity in the form of aerobic physical exercise to lose weight in adolescents who are obese. The objective of this study is to examine the effect of physical activity on weight loss of obese students at SMK Negeri 3 Salatiga.

\section{Method}

The type of research used is quantitative research with a quasiexperimental model to determine the effect of physical activity in the form of aerobic physical exercise on weight loss for obese students at SMK Negeri 3 Salatiga. Physical activity can help a person lose weight if it is done regularly at least 3 times a week with a duration of 30 minutes each time and is done for 12 weeks (Sientia, 2012). The research was conducted for 1 month at SMK Negeri 3 Salatiga. Research respondents were students of SMK Negeri 3 Salatiga grade X and XI who were obese based on anthropometric measurements (BMI> $27 \mathrm{~kg} /$

PJKR_

https://jurnal.unimed.ac.id/2012/index.php/jpehr 
$\mathrm{m} 2$ ) and were willing to become research respondents through filling out informed consent.

The research instrument in the form of a measuring tool for body height and weight to determine the Body Mass Index (BMI), where the clarification of the body mass index included very thin $(<17 \mathrm{~kg} / \mathrm{m} 2)$, thin $(17.0-18.4 \mathrm{~kg} / \mathrm{m} 2)$ normal $(18.5-25.0 \mathrm{~kg} / \mathrm{m} 2)$, overweight $(25.1-27.0 \mathrm{~kg} / \mathrm{m} 2)$, and obesity $(>27.0$ $\mathrm{kg} / \mathrm{m} 2$ ) (Harahap et al., 2014). The formula for BMI = Weight / Height2, the GPAQ form for determining the level of physical activity, a body fat monitor to determine the respondent's fat content, and a questionnaire sheet to determine the respondent's lifestyle. The experimental method used was to provide physical activity treatment in the form of aerobics with a frequency of 3 times a week for \pm 1 month with a total of 1-time exercise for 30 minutes to obese students. Aerobic exercises include jogging, pushups, and sit ups to help burn calories (Table 1). Measurement of body weight and fat content is carried out gradually once a week. This aerobic physical exercise program is the initial stage in an effort to familiarize participants with physical activity with long-term goals for weight loss.

Table 1. Aerobic Physical Exercise Program for 1 Month

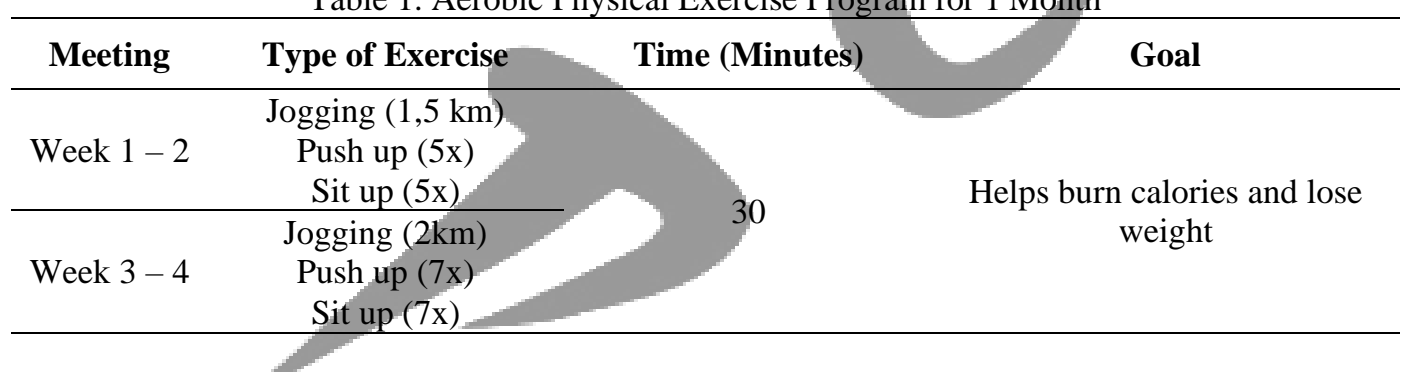

Analysis of research data includes the stages of univariate and bivariate data analysis. Univariate dafa analysis rincludes idescriptive cinformation from respondents which is displayed in tabular form, while bivariate data analysis will be carried out using Paired Samples $\mathrm{T}$ Test to test before and after aerobic exercise.

\section{Result and Discussion}

The characteristics of the respondents obtained were that 10 students had a body weight of $80-90 \mathrm{~kg}$, while 10 students had a weight of $91-157 \mathrm{~kg}$. The body fat monitor tool was used to examine the effect of physical activity on weight loss for obese students at SMK Negeri 3 Salatiga.

Table 2. Average changes in body composition based on Body Fat Monitor measurements

\begin{tabular}{l|c|c|c}
\hline \multicolumn{1}{c|}{ Parameter } & Before & After & Weight Loss (\%) \\
\hline Weight & 94,79 & 91,75 & 3 \\
\hline Fat & 26,9700 & 24,9000 & 8 \\
\hline RM & 1960,0500 & 1891,1500 & 4 \\
\hline BMI & 33,5850 & 32,7550 & 2 \\
\hline
\end{tabular}

PJKR_

https://jurnal.unimed.ac.id/2012/index.php/jpehr 


\begin{tabular}{c|c|c|c}
\hline Skin layer & 20,2300 & 19,3400 & 4 \\
\hline Chest cavity & 19,1900 & 18,3000 & 5 \\
\hline Arms & 28,1400 & 26,7600 & 5 \\
\hline Legs & 28,0150 & 27,2350 & 3 \\
\hline Body frame & 30,6500 & 29,6000 & 3 \\
\hline Chest cavity & 23,5050 & 23,0150 & 2 \\
\hline Arms & 35,7050 & 34,9750 & 2 \\
\hline Legs & 48,1450 & 47,2650 & 3 \\
\hline BMI & 33,5215 & 32,4430 & 2 \\
\hline
\end{tabular}

Based on the results in Table 2, it can be concluded that all respondents experienced changes in decreased body composition by using the Body Fat Monitor which includes body weight, fat, RM (Resting Metabolism), BMI (Body Mass Index), skin layer (chest cavity, arms, and legs), body frame (chest cavity, arms and legs) and BMI ranging from $2 \%-8 \%$.

Table 3 contains the results of statistical tests using the Paired Samples T Test. Based on all tests on the existing measurement parameters, the results showed that only measurements of the body frame in the chest cavity had no significant difference either before or after physical activity with a significance value> $0.05(0.231,0.013>0.05)$.

Table 3. Comparative test of body composition measurement with paired sample t test

\begin{tabular}{|c|c|c|c|}
\hline Parameter & t Value & Sig. & Description \\
\hline Weight & 9.747 & .000 & $\sqrt{ }$ \\
\hline Fat & 10.282 & .000 & $\sqrt{ }$ \\
\hline $\mathrm{RM}$ & 6.197 & .000 & $\sqrt{ }$ \\
\hline BMI & 9.216 & .000 & $\sqrt{ }$ \\
\hline Skin Layer & 9.432 & .000 & $\sqrt{ }$ \\
\hline Chest cavity al phy & sical F 13.990 tion & eglth gro00 Recreat & tion \\
\hline Arms publowes cr & 2.735 & .013 & - \\
\hline Legs Btwot Progom porth & 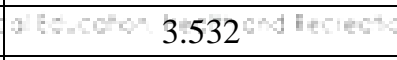 & .002 & $\sqrt{ }$ \\
\hline Body Frame & 7.550 & .000 & $\sqrt{ }$ \\
\hline Chest cavity & 1.239 & .231 & - \\
\hline Arms & 5.050 & .000 & $\sqrt{ }$ \\
\hline Legs & 7.055 & .000 & $\sqrt{ }$ \\
\hline BMI & 9.289 & .000 & $\sqrt{ }$ \\
\hline
\end{tabular}

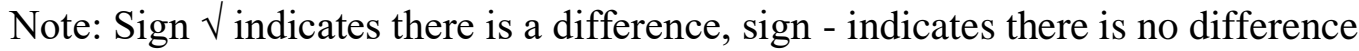

Weight

Based on the calculation of the average weight loss rate in Table 1 and Table 2, all respondents experienced weight loss after doing physical activity exercises in the form of jogging, push-ups, and sit-ups which were carried out regularly 3 times a week for 1 month with a duration of about 30 minutes in one treatment. The average weight loss represents $3 \%$ of the previous body weight.

PJKR_

https://jurnal.unimed.ac.id/2012/index.php/jpehr 
According to (Arywibowo \& Prihartanti, 2009), to provide meaningful changes to the health of someone who is overweight, he must lose $5-10 \%$ of his previous body weight. The results of this study have not provided significant changes for the health of the respondents.

\section{Body Mass Index (BMI)}

BMI is a form of measurement that is used to measure body composition using body weight and height and then measured by the BMI formula (Habut et al., 2015). BMI is a method used in determining a person's nutritional status. Based on the results of the calculation of the average BMI before and after, the respondents experienced a change of about 3\% from 33.5215 to 32.443 , but this has not significantly changed the BMI status of the respondents. To reduce the nutritional status of obesity to at least overweight, a $6.6 \%$ reduction from the initial BMI is required.

\section{Dietary Habit}

Talking about changes in body weight will not be separated from the diet and nutritional intake. Physical activity is useful for burning/calories (Hendra, 2016). Nutritional intake and diet must also be done together so that calorie burning can be effective. Less and more nutritional status can be influenced by dietary factors (Danty et al., 2019). A diet low in fiber can be a risk factor for obesity and DCS (Disease of Circulatory System). Those who are not satisfied with their body shape will limit their food consumption, even go on a strict diet without supervision from nutritionists or health experts (Widianti \& Kusumastuti, 2012). A diet high in fiber can lose weight, if you consume soluble fiber regularly such as pectin, gums, mucilage, and a number of hemicellulose, pectin, gum, and musilago are part of plant food cells. This fiber is found in many fruits, vegetables and nuts (A. Santoso, 2011). This fiber has the ability to absorb water and form a thick liquid in the digestive tract, so that foods rich in water fiber provide a longer feeling of fullness and can prevent consuming more food. Foods that contain high crude fiber usually contain low sugar levels, low calories, and low-fat control treatment group variables that can reduce weight gain (Maryusman et al., 2018).

Based on the results of the available data, there has been no significant change in body weight and BMI, therefore the nutritional aspect needs to be monitored continuously. One thing to watch out for is that the nutritional intake of adolescents becomes difficult to control because of their tendency to continue to eat what they like. Excessive love for certain foods causes nutritional needs not being met optimally and nutrition in the body is not balanced. For example, student A really likes to eat geprek in the school canteen, every break he will come to buy the food. As a result, the incoming nutrition is not balanced because students rarely consume vegetables and fruits. In fact, how many calories are consumed in a day will affect changes in a person's nutritional status. To lose weight, a person needs to reduce calorie intake by 500 calories per day (Arywibowo \& Prihartanti, 2009). 
During the research process, all respondents obeyed the rules that have been given by the adult calorie needs of around 2,000 per day, while to reduce it, among others, by adjusting the diet and following the prescribed mealtime rules. Therefore, it can be concluded that all respondents are aware of themselves in losing weight. Apart from that, diet is also a problem that is difficult for vocational students to separate from due to irregular eating hours. Students have difficulty regulating meal times because of erratic activities. For example, on Monday the respondent has lunch at $2 \mathrm{pm}$ after school, but on Tuesday the respondent has lunch later because there are extracurricular activities after class ends. The risk of obesity can be avoided by providing recommendations for respondents not to get hungry easily, and respondents are also advised to eat foods high in fiber such as fruits and vegetables so that the calories that enter are not as big as fried or other instant foods.

The Effect of Physical Activity on Weight Loss

Many ways to lose weight include exercising, such as jogging, swimming, stationary bikes, fitness, aerobics, taking diet drugs, drinking slimming milk, to dieting by reducing the number of calories that are entered (Kedokteran et al., 2014). Apart from the above activities, weight loss can also be done with aerobic exercise (Sientia, 2012). Physical exercises such as jogging, pushups, and sit ups are physical activities that can be done to lose weight, especially those who are obese. Based on the results of research, body weight has been reduced by $3 \%$ with a duration of 30 minutes for weeks 1 to 4 , each exercise 3 times a week for one month. It takes a longer time, namely $2-3$ months to lose $5 \%-10 \%$ of body weight (Utomo et al., 2012). It takes consistency to exercise 3 times a week for 2 3 months by adjusting nutritional intake and diet so that weight loss is more meaningful.

\section{Conclusion}

\section{Journal Physical Education. Health and Recreation}

From the results of this study it can be concluded that students who are obese with physical exercise jogging, pushups and sit ups for one month with a duration of 30 minutes in 1x exercise and carried out 3 times a week, can get a weight loss of $3 \%$ and BMI has decreased by $3 \%$. However, to lose $5-10 \%$ weight, consistency is needed to exercise 3 times a week for 2-3 months by adjusting nutrient intake and eating habits so that weight loss is more optimal. This is one of the limitations of the researcher and is expected to be one of the considerations for further research.

\section{References}

A. Santoso. (2011). Serat Pangan (Dietary Fiber) Dan Manfaatnya Bagi Kesehatan. Magistra, 75. https://doi.org/10.1108/eb050265

Aini, S. N. (2013). Faktor Risiko Yang Berhubungan Dengan Kejadian Gizi Lebih Pada Remaja Perkotaan. Unnes Journal of Public Health, 3(1), 1-10.

PJKR_

https://jurnal.unimed.ac.id/2012/index.php/jpehr 
Arywibowo, D. M., \& Prihartanti, N. (2009). Penurunan Berat Badan pada Obesitas Melalui Pengaturan Diri. Jurnal Penelitian Humaniora, 10(2), 199-211.

Danty, F. R., Syah, M. N. H., \& Sari, A. E. (2019). Hubungan Indeks Gizi Seimbang Dengan Status Gizi Pada Remaja Putri Di SMK Kota Bekasi. Jurnal Kesehatan Indonesia, 10(1), 43-54.

Habut, M. Y., Nurmawan, I. P. S., \& Wiryanthini, I. A. D. (2015). Hubungan Indeks Massa Tubuh dan Aktivitas Fisik terhadap Daya Tahan Kardiovaskular pada Mahasiswa Fakultas Kedokteran Universitas Udayana. Erepo Unud, 831, 1-14.

Harahap, H., Widodo, Y., \& Mulyati, S. (2014). Penggunaan Berbagai Cut-Off Indeks Massa Tubuh Sebagai Indikator Obesitas Terkait Penyakit Degeneratif Di Indonesia. Gizi Indonesia, 28(2). https://doi.org/10.36457/gizindo.v28i2.20

Harikedua, V. T., \& Tando, N. M. (2012). Aktivitas Fisik Dan Pola Makan Dengan Obesitas Sentral Pada Tokoh Agama Di Kota Manado. Gizido, 4(1), 289-298.

Hendra. (2016). Hubungan aktifitas fisik dengan kejadian obesitas pada wanita di kota malang. Universitas Negeri Malang, 7, 26-32.

Kedokteran, F., Sam, U., Manado, R., Nussy, C. Y., Ratag, G. A. E., \& Mayulu, N. (2014). Analisis Upaya-Upaya Penurunan Berat Badan Pada Mahasiswi Angkatan 2010 Fakultas Kedokteran Universitas Sam Ratulangi Manado. Jurnal Kedokteran Komunitas Dan Tropik, 2(2), 81-84.

KEMENKES, R. (2013). Riset Kesehatan Dasar 2013. https://doi.org/10.1517/13543784.7.5.803

Kosnayani, A., \& Aisyah, I. (2016). Faktor Risiko Yang Berhubungan Dengan Obesitas Remaja. Siliwangi, 2(2), 128.

Kurdanti, W., Suryani, I., Syamsiatun, N. H., Siwi, L. P., Adityanti, M. M., Mustikaningsih, D., \& Sholihah, K. I. (2015). Risk Factors For Obesity In Adolescent. Jurnal Gizi Klinik Indonesia, 11(4), 179-190. https://doi.org/10.22146/ijcn.22900

Maryusman, T., Fauziyah, A., Fatmawati, I., Firdausa, N. I., \& Imtihanah, S. (2018). Pengaruh Kombinasi Diet Tinggi Serat dan Senam Aerobik terhadap Penurunan Berat Badan. Jurnal Kedokteran Dan Kesehatan, 14(1), 56. https://doi.org/10.24853/jkk.14.1.56-62

Nurcahyo, F. (2011). Kaitan Antara Obesitas dan Aktivitas Fisik. Medikora, VII(April), 87-96.

Sari, A. M., Ernalia, Y., \& Bebasari, E. (2017). Hubungan Aktivitas Fisik dengan Kejadian Obesitas pada Siswa SMPN di Pekanbaru. Jurnal Online Mahasiswa Fakultas Kedokteran Universitas Riau, 4(1), 1-8.

Sientia, F. (2012). Pengaruh Latihan Senam Aerobik Terhadap Perubahan Berat Badan Pada Peserta Klub Kebugaran. Jurnal Kedokteran Diponegoro, 1(1).

Sofa, I. M. (2018). Kejadian Obesitas , Obesitas Sentral, dan Kelebihan Lemak Viseral pada Lansia Wanita The Incidence of Obesity , Central Obesity ,

PJKR_ 
and Excessive Visceral Fat among Elderly Women. 228-236. https://doi.org/10.20473/amnt.v2.i3.2018.228-236

Turege, J. N., Kinasih, A., \& Kurniasari, M. D. (2019). Hubungan Antara Aktivitas Fisik Dengan Obesitas Di Puskesmas Tegalrejo, Kota Salatiga. Jurnal Ilmu Keperawatan Dan Kebidanan Vol.10, 10(1), 256-263.

Utomo, G. T., Junaidi, S., \& Rahayu, S. (2012). Latihan senam aerobik untuk menurunkan berat badan. Journal of Sport Science and Fitness, 1(1), 6-10.

Widianti, N., \& Kusumastuti, A. C. (2012). Hubungan Antara Body Image Dan Perilaku Makan Dengan Status Gizi Remaja Putri Di Sma Theresiana Semarang. Journal of Nutrition College, 1(1), 398-404. https://doi.org/10.14710/jnc.v1i1.379

Wijayanti, D. N. (2013). Analisis Faktor Penyebab Obesitas Dan Cara Mengatasi Obesitas Pada Remaja Putri (Studi Kasus Pada Siswi SMA Negeri 3 Temanggung). Skripsi.

Yuksel, H. S., Şahin, F. N., Maksimovic, N., Drid, P., \& Bianco, A. (2020). School-based interyention programs for preventing obesity and promoting physical activity and fitness: A systematic reyiew. International Journal of Environmental Research and Public Health, 17(1). https://doi.org/10.3390/ijerph17010347

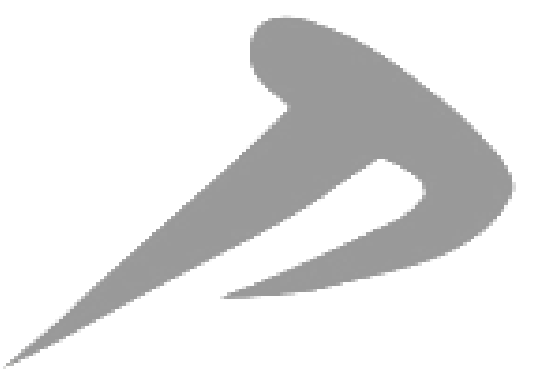

Journal Physical Education. Health and Recreation

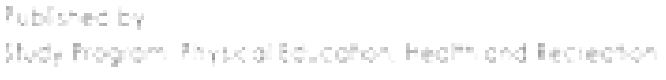

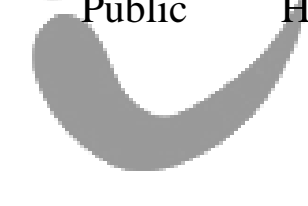

